\title{
Technological Defects Faced by the High School Students and Setbacks in their Performance
}

\author{
M. Sankar, S. Barani Chelvi, B. Venkata Srilatha,
}

\begin{abstract}
The purpose of the present paper is to identify the role of A Study on Teaching Methods and Students' performance management Students performance. The factors of student's performance such as Teaching Styles (exogenous variable) and Students performance (Endogenous variable) are measured. The endogenous item is students' perception is measured as single. Method:
\end{abstract}

Survey method was used in the study to collect the data; Structured Questionnaire was distributed to 115 respondents of students (male and female). 15 Questionnaires were found to be unfilled so total 100 respondents $(n=100)$. CFA and SEM were the statistical tools applied for the analysis in AMOS-21 to check the hypothesis of learn.

Findings:

The study is portraying on positive and significant relation among the exogenous is level of academic challenge and the endogenous is students' performance.

Suggestion:

The results display on the paper level of academic challenge and students perception.

Uniqueness - This study is an initial try to know, and 'enhance thelevel of academic challenge variables relating to students' performance of management Students in Indian context. Limitations:

Time period is another factor limitation for the study. Hence findings cannot be generalized.

Key words - students' performance, Teaching Methods

\section{INTRODUCTION}

In this study we had to concentrate the level of university smart class like Teaching Methods and students perception. Most of the studies to explain students' perception to measure the examination like GPA. The integer knowledge and skill

oriented study and college environment and play for

students games for the example of volleyball, athletics, and

Revised Manuscript Received on December 30, 2019.

M. Sankar, Assistant Professor, Department Of Science and Humanities ,Bharath Institution Of Higher Education And Research TamilNadu,IndiaEmail: sankar06.phd@gmail.com

S. Barani Chelvi, Assistant Professor, Department Of Science and Humanities, Bharath Institution Of Higher Education And ResearchTamilNadu,India Email: baranikarthi1629@gmail.com

T. B. Venkata Srilatha Assistant Professor, Department Of Science and Humanities, Bharath Institution Of Higher Education And Research TamilNadu,IndiaEmail: bvsrilatha27@gmail.com cricket to refresh our mind. The primary role of theory to concentrate for play a vital role for better living (Battle \& Lewis, 2002). The company to expect more than output for our company role, maximum product for maximum gain to increase national economic (Saxton, 2000). The factors that influence most of the researcher to follow for respondents details (Gender, age, education, family income, Parents education) (Crosnoe, Johnson \& Elder, 2004). The proper role of this demographic factors in 18th century (Mann, 1985). These commonly classify the Umbrella of demography (Ballatine, 1993). The most of the talent persons to explain that socio-economic concentrate students' perception to measures for economic. Well being today economic one of the powerful and basic needs of human wants (Adams, 1996). The economically weak students low results for our perceptions (US Department of Education, 2003).[1]-[4]

\section{A. Explanation of the issue}

Numerous specialists broke down understudy's introduction (execution) by GPA and CGPA was found. In this articles pursued by Grade point esteem. A few analysts to looking at the quarterly, half yearly and every year to gather the student progress in required explore. The point of the present investigation was concentrate student's learning and result of the presentation (test results) was determined by GPA.

\section{B. Reasonable Model}

A model system prescribed by past study NSSE George Kuh-Sep(2018) model was taken as a base model for the examination. They are level of scholarly challenge, and understudies' exhibition. The analyst has tried this edge work as poll, conveyed to the understudies of the executives contemplates in a University - instruction foundation.[5]-[10]

C. Author's Model

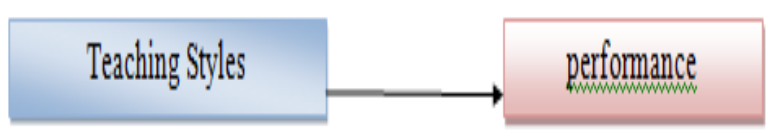

Fig.1. Theoretical Model

\section{REVIEW OF LITERATURE:}

Education is one of the powerful tool in the world most of the country to create awareness about education. Education has

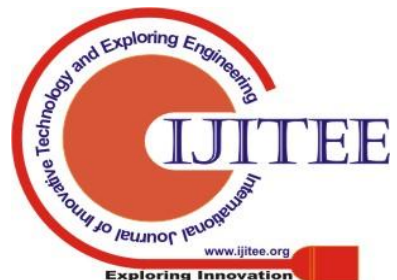


changed our knowledge, skills, self confidence, and balance of our economic status to change of learnrs (Tsinidou, Gerogiannis, \& Fitsilis, 2010). The define of educational various from country to country culture difference (Michael, 1998). These societal has vital role of goal setting of students perception (Goddard, 2003). The involved social structure mentions that parents concentrate children's education increase the educational achievement of their children (Furstenberg \& Hughes, 1995).[11]-[14]

The correlation between male and female the educational success of students has been discuss for ten years (Eitle, 2005). Who are professionally qualified students'femaledisplays better than maleperformance (Chambers \& Schreiber, 2004). Male and female and parents profession are positive contributor to student success (McCoy, 2005; Peng \& Hall, 1995). A research study which highlights the opinion of male and female, discusses that female students perform better when compared to male students.

Teaching Methods

The limited studies published shows that have empirically investigate of the idea on academic performance have emphasized the concept's contextualized nature. Miller and Shih (1999) survey was 262 faculties about their perceptions of the differences in the analogous concept of academic severity levels between on-campus and off-campus courses. At their institution, off-campus courses are delivered electronically, or they are taught traditionally at a site off campus. Their survey characterize academic challenge in several ways: as demanding high achievement (Braxton, 1993), as challenging students to struggle for fineness (Unks, 1979), and as engaging students in active learning. The authors believed, however, that these perceptions alone were not strong enough evidence to suggest that the teaching for rigor was different between the two types of courses. The National Survey of Student Engagement (2012), often referred to as the NSSE, provides higher education institutions with students' reflections on their learning, including academic challenge, and on their participation in education-related programs and activities. The

\section{A. Academic Performance:}

Students' performance is the basic concept of schools, college, and University. Students is one of the fundamental asset of university, because the first person of the institution to produced economic under hold on our hand, but student management is basically arts, because each and every student measure the difficult to understand one person to other. Commonly to explain students is most powerful persons because to divide all job only students. Students performance has been measures our knowledge, practical skills, lab skills etc. The most of the educational institution measure only for students' examination like GPA and CGPA. Students' performance has been argued among teacher, employees, and Dean of the institution. Students' perception has been lots of study that sounds good. The previous findings explain work hard, education level of parents, previous university, family income and factors of self motivation have been positive outcome on the students GPA. The study on students' perception measure on GPA. The item that support affect student's performance Academic challenge. The results also show that academic challenge management students' performance is strong support.[15]-[20]

\section{Research question:}

1. Does level of Teacher styles and performance of students?

\section{OBJECTIVE OF THE STUDY:}

1. To analyze the association among level of Teaching Styles and students' performance.

\section{Hypotheses}

H1. There is positive relation amongTeaching styles and Academic performance.

\section{MATERIALS AND Methods}

The examination was done the relationship between level of scholastic test and understudies' presentation estimated among 115 administration understudy. The improve of concentrate through survey while in transit to discover the ICT in understudies' presentation.

\section{RESULTS \& DISCUSSION}

The respondents of this examination comprise of Management understudies' at the private college. Review strategies were utilized for the exploration study. The all out number of understudies (male and female) of the understudies' organized Questionnaire was appropriated to 135 respondents of understudies (male and female). 35 Questionnaires was seen as unfilled so absolute 100 respondent filled quality survey[21]-[24]

\section{Data Analysis Table I. Overall Reliability of the Data}

\begin{tabular}{|l|l|}
\hline Alpha( $(0)$ std. things & Number of things \\
\hline 87 & 15 \\
\hline
\end{tabular}

\begin{tabular}{|l|l|l|}
\hline Variables & $\begin{array}{l}\text { Cronbhach's } \\
\text { Alpha }\end{array}$ & No of Item \\
\hline $\begin{array}{l}\text { Students } \\
\text { performance }\end{array}$ & .899 & 11 \\
\hline ICT & 977 & 12 \\
\hline
\end{tabular}

By and large unwavering quality instrument concentrate 
was 0.837 . The present investigation to look at unwavering quality of the general Item is 0.837 is huge individual alpha (ICT) is 0.977 and subordinate variable Student execution is 0.899 the all in all 0.837 .It is worth note that 0.70 ought to be a sufficient alpha worth coefficient still lower coefficients utilized in a couple of research.

Sample Adequacy Table II. (KMO)

\begin{tabular}{|c|c|c|}
\hline Sample adequacy KM & & .79 \\
\hline \multicolumn{3}{|l|}{ Adequacy. } \\
\hline \multirow[t]{3}{*}{ B T S } & & 1175.769 \\
\hline & Degrees of freedom & 55 \\
\hline & Significance. & 0.000 \\
\hline
\end{tabular}

The value received through KMO test was. 839 which is above the threshold value of (0.7). The Chi-square value was 1175.769, Degrees of freedom (DF) was 55 and the significant $\mathrm{p}$ value is .000 . Hence the sample taken for the study is adequate in nature.

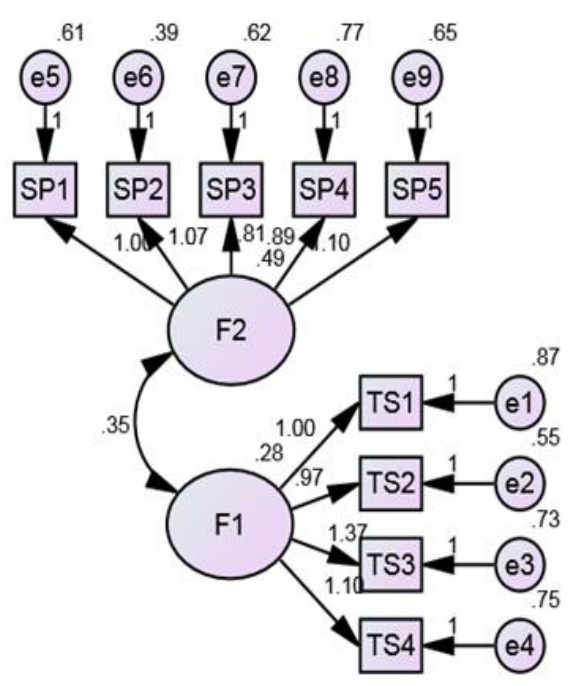

Diagram 1 Showing CFA analysis

Table III

\begin{tabular}{|l|l|}
\hline Fit Indices & Results \\
\hline Chi-square & 0.177 \\
\hline CMIN/DF & 3.123 \\
\hline P & .000 \\
\hline GFI & 0.915 \\
\hline AGFI & 0.937 \\
\hline NFI & 0.940 \\
\hline TLI & 0.939 \\
\hline CFI & 0.973 \\
\hline RMSEA & 0.057 \\
\hline
\end{tabular}

Results that portray from the CFA model summary step by step: $\mathrm{GFI}=0.915, \mathrm{P}$ value $=0.000$ of Chi-square $=0.177$ that is positive $(<0.05)$ illustrate model is good. The value of CIMIN/DF is 3.123, AGFI is 0.937, NFI is 0.940, TLI is $0.939, \mathrm{CFI}$ is 0.983 and RMSEA is 0.057 . Positive correlation between Independent variable- levels of academic challenge, Dependent- student performance. Hence the above factors are confirmed in the study.

Table IV showing testing of Hypothesis

Table IV showing testing of Hypothesis

\begin{tabular}{|l|}
\hline Variables The relation Hypothesis \\
\hline ICT Students perfommanceSupported \\
The tested hypothesis as per regression analysis proves to be significant.
\end{tabular}

\section{Path Analysis}

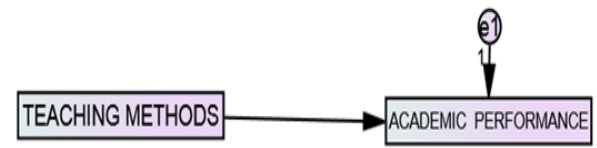

\section{Diagram 1 Showing CFA analysis}

\section{Discussion:}

The path analysis done using SEM analysis has helped to Identified the model. The values $\mathrm{GFI}=\quad 1.00, \quad \mathrm{CFI}=1.00$, 
RMSEA $=.0453$ confirmed that level of academic challenge has on effect over the students' academic performance.

\section{Conclusion:}

This study was carried to explain the role of level of academic challenge and the variables do play a vital role in the students' performance. Level of academic challenge has been one of the weak areas in the field of Indian education, but it has started to gain momentum. Future studies with more mediation variables like gender and GPA can be used.

\section{REFERENCES}

1. $\quad$, S. \& Rabiyathul Basariya, S. 2019, "Influence of value analysis and cross training in industry", International Journal of Engineering and Advanced Technology, vol. 8, no. 6, pp. 1810-1811.

2. Velvizhi, R., Sri Gowtham, S. \& Jeya Priya, D. 2019, "Examination of early feedbacks for effective product retailing on E-commerce websites", International Journal of Engineering and Advanced Technology, vol. 8, no. 6 Special Issue 2, pp. 703-706.

3. Anuradha, C., Pothumani, S. \& Kavitha, R. 2019, "A novel method towards E-commerce", International Journal of Engineering and Advanced Technology, vol. 8, no. 6 Special Issue 2, pp. 535-538.

4. Thomas, J. \& Rabiyathul Basariya, S. 2019, "A study on the issues of financial ratio analysis", Indian Journal of Public Health Research and Development, vol. 10, no. 3, pp. 1079-1081.

5. Ramachandran, S. \& Rabiyathul Basariya, S. 2019, "Online marketing - study on customer satisfaction and relationship", Indian Journal of Public Health Research and Development, vol. 10, no. 3, pp. 1072-1078.

6. Priya, R., Vinothini, G. \& Cor Jesu, C.D. 2019, "The mentor-protégé relationship for professional growth", Journal of Advanced Research in Dynamical and Control Systems, vol. 11, no. 9 Special Issue, pp. 1110-1119.

7. Jannifer Rani, N., Bina Pani, S. \& Nimisha, N.S. 2019, "A study on money back polices available in LIC", Journal of Advanced Research in Dynamical and Control Systems, vol. 11, no. 9 Special Issue, pp. 833-839.

8. Saillaja, V., Jhansi Rani, K. \& Catherine, R. 2019, "Global marketing management planning and organization", Journal of Advanced Research in Dynamical and Control Systems, vol. 11, no. 9 Special Issue, pp. 489-493

9. Saillaja, V., Jhansi Rani, K. \& Catherine, R. 2019, "The new phase of marketing information system", Journal of Advanced Research in Dynamical and Control Systems, vol. 11, no. 9 Special Issue, pp. 482-488.

10. Thoufiqulla \& Raju, D.V. 2019, "Perception of indian investor towards investment in mutual funds with special reference to mip funds", Journal of Advanced Research in Dynamical and Control Systems, vol. 11, no. 5, pp. 177-183.

11. Jasmine, K.R.M. \& Basariya, S.R. 2018, "A study on the customers benefits on mutual funds", International Journal of Civil Engineering and Technology, vol. 9, no. 4, pp. 45-48.

12. Vasanthi, S. \& Basariya, S.R. 2019, "Pros and cons of on the job training versus off the job training", International Journal of Scientific and Technology Research, vol. 8, no. 10, pp. 671-674.

13. Pavithra, J. \& Ganesan, M. 2016, "A study on awareness and impact of micro-financial schemes", International Journal of Applied Business and Economic Research, vol. 14, no. 8, pp. 5449-5460.

14. Pavithra, J., Dilli Babu, P. \& Ambuli, T.V. 2014, "A study on budgetary control at Maruti Service Masters, Chennai", International Journal of Applied Business and Economic Research, vol. 12, no. 2, pp. 151-161.

15. Gunaraja, T.M. \& Venkatrama Raju, D. 2018, "Determining factors of organisational climate with reference to leadership styles", International Journal of Mechanical Engineering and Technology, vol. 9, no. 9, pp. 1327-1332.

16. Gunaraja, T.M. \& Venkatrama Raju, D. 2018, "The role of job satisfaction and training of employees in determining organisational climate of a selected industry", International Journal of Civil Engineering and Technology, vol. 9, no. 8, pp. 1266-1269.

17. Aarathy, T.S. \& Raju, D.V. 2018, "Performance appraisal and its effects on employees with respect to it sector in Chennai city", International Journal of Civil Engineering and Technology, vol. 9, no. 6, pp. 1535-1538.

18. Aarathy, T.S. \& Raju, D.V. 2018, "Employee perception towards performance appraisal system in IT sector", International Journal of Mechanical Engineering and Technology, vol. 9, no. 5, pp. 131-135.

19. Porselvi, W., Jublee, D. \& Sivanesan, G. 2018, "A study on factors influencing adoption of technology and innovation in banking industry, tamilnadu, India", International Journal of Mechanical Engineering and Technology, vol. 9, no. 5, pp. 789-800.

20. Akessa, G.M. and Dhufera, A.G., 2015. Factors That Influences Students Academic Performance: A Case of Rift Valley University, Jimma, Ethiopia. Journal of Education and Practice, 6(22), pp.55-63.

21. Miller, G. and Shih, C.C., 1999. A faculty assessment of the academic rigor of on-and off-campus courses in agriculture. Journal of Agricultural Education, 40, pp.57-65.

22. Tsinidou, M., Gerogiannis, V. and Fitsilis, P., 2010. Evaluation of the factors that determine quality in higher education: an empirical study. Quality Assurance in education, 18(3), pp.227-244.

23. Farooq, M.S., Chaudhry, A.H., Shafiq, M. and Berhanu, G., 2011. Factors affecting students' quality of academic performance: a case of secondary school level. Journal of quality and technology management, 7(2), pp.1-14.

24. Fitsilis, P., Gerogiannis, V. and Anthopoulos, L., 2014. Ontologies for software project management: a review. Journal of Software Engineering and Applications, 7(13), p.1096.

25. Adams, J.D. and Jaffe, A.B., 1996. Bounding the effects of $R \& D$ : an investigation using matched establishment-firm data(No. w5544). National bureau of economic research

\section{AUTHORS PROFILE}

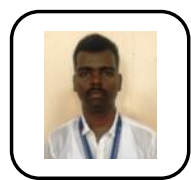

M. Sankar, Assistant Professor, Department Of Science and Humanities, Bharath Institution Of Higher Education And Research TamilNadu,India

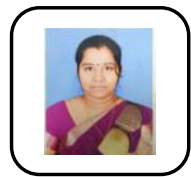

S. Barani Chelvi, Assistant Professor, Department Of Science and Humanities, Bharath Institution Of Higher Education And Research TamilNadu, India

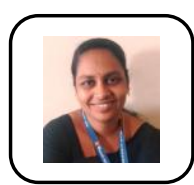

T. B. Venkata Srilatha Assistant Professor, Department Of Science and Humanities, Bharath Institution Of Higher Education And Research TamilNadu,India 